\title{
Trypanocide treatment among adults with chronic Chagas disease living in Santa Fe City (Argentina), over a mean follow-up of 21 years: parasitological, serological and clinical evolution
}

\author{
Tratamento tripanocida em adultos chagásicos crônicos, residentes na Cidade de \\ Santa Fé (Argentina), com seguimento de 21 anos em média: \\ evolução parasitológica, sorológica e clínica
}

\author{
Diana L. Fabbro ${ }^{1}$, Mirtha L. Streiger ${ }^{1}$, Enrique D. Arias ${ }^{1}$, María L. Bizai ${ }^{1}$, Mónica del Barco ${ }^{1}$ \\ and Norberto A. Amicone ${ }^{1}$
}

\begin{abstract}
The efficacy of treatment with nifurtimox and/or benznidazole among adults with chronic Chagas disease with no previous electrocardiographic disturbances was evaluated over a mean follow-up of 21 years, by means of conventional serology, xenodiagnosis, clinical examination, electrocardiograms and chestX-ray. One hundred and eleven patients, between 17 and 46 years old, were studied: 54 underwent treatment (nifurtimox 27, benznidazole 27) and 57 remained untreated (controlgroup). Xenodiagnosis wasperformed on $65 \%$ of them:36/38 of the treated and $9 / 34$ of the untreated patients had previous positive xenodiagnosis. Post-treatment, 133xenodiagnoses were performed on 41 patients, all resulting negative. In the control group, 29 xenodiagnoses were performed on 14 patients; 2 resulted positive. Sera stored during the follow-up were simultaneously analyzed through conventional serology tests (IHA; DA-2ME; IIF). The serological evolution in the treated group was: a) $37 \%$ underwent negative seroconversion (nifurtimox 11, benznidazole 9); b) 27.8\% decreased titers (nifurtimox 9, benznidazole 6), 9 showed inconclusive final serology (nifurtimox 7, benznidazole 2); c) 35.2\% remained positive with constant titers (nifurtimox 7 ; benznidazole 12). The control group conserved the initial antibody levels during the follow-up. In the clinical evolution, 2/54 (3.7\%) of the treated and 9/57 (15.8\%) of the untreated patients showed electrocardiographic disturbances attributable to Chagas myocardiopathy, with a statistically relevant difference $(p<0.05)$. Treatment caused deparasitation in at least $37 \%$ of the chronically infected adults and a protective effect on their clinical evolution.
\end{abstract}

Key-words: Chagas disease. Treatment. Chagasic patients. Follow-up.

\section{RESUMO}

Avaliamos a eficácia do nifurtimox e/ou benznidazol, durante 21 anos em média, em adultos chagásicos crônicos sem alterações eletrocardiográficas iniciais, mediante sorologia convencional, xenodiagnóstico, exames clínicos, eletrocardiográficos e radiografia do tórax. Estudamos 111 pacientes (17 a 46 anos): 54 foram tratados (27 com nifurtimox e 27 com benznidazol) e 57 formaram o grupo controle. Foram submetidos ao xenodiagnóstico 65\% dos pacientes estudados: 36/38 tratados e 9/34 do grupo controle com xenodiagnóstico positivo prévio. Após tratamento, foram realizados 133 xenodiagnósticos em 41 pacientes, sendo todos negativos. Foram realizados 29 xenodiagnósticos em 14 pacientes do grupo controle, 2 foram positivos. A sorologia convencional foi realizada em soros estocados durante o seguimento. Evolução sorológica. Grupo tratado: a) 37\% negativaram (nifurtimox 11, benznidazol 9); b) 27,8\% diminuíram a titulação (nifurtimox 9, benznidazol 6), 9 deles apresentaram sorologia final discordante (nifurtimox 7, benznidazol 2; c) 35,2\% permaneceram positivos com titulação constante (nifurtimox 7, benznidazol 12). Grupo controle: conservou os níveis iniciais de anticorpos durante o seguimento. Evolução clínica: 2/54 (3,7\%) pacientes tratados e 9/57 não tratados apresentaram alterações eletrocardiográficas atribuíveis a miocardiopatia chagásica. Diferenças estatisticamente significantes $(p<0,05)$. O tratamento produziu efeito de combate ao parasita em pelo menos $37 \%$ dos infetados crônicos adultos e efeito protetor na evolução clínica.

Palavras-chaves: Doença de Chagas. Tratamento. Pacientes chagásicos. Seguimento.

\footnotetext{
1. Centro de Investigaciones sobre Endemias Nacionales, Facultad de Bioquímica y Ciencias Biológicas, Universidad Nacional del Litoral (UNL), Santa Fe, Argentina

Financiado por UNL para proyectos CAI+D.

Address to: Dra. Diana L. Fabbro. 25 de Mayo 1524, 3000 Santa Fe, Santa Fe, Argentina.

Tel: 5403424595085

e-mail: dfabbro@fbcb.unl.edu.ar

Recebido para publicação em 19/7/2006

Aceito em 7/1/2007
} 
The importance of administering trypanocide treatment to individuals with chronic Chagas disease, using the drugs available for clinical use, has been highly controversial because of the lack of evidence regarding its effectiveness for achieving complete deparasitation and regarding the role attributed to T. cruzi in perpetuating the cardiac damage $e^{11} 14152331$. Evaluation of such treatment at this stage of the infection requires long-term followup studies, because of the slow disease progression; reactive persistence of conventional serology, even a long time after the treatment has been completed; and the lack of high sensitivity parasitological methods.

Many studies on trypanocide treatment in patients who had chronic infection ${ }^{1379161819243032}$ have shown great variability in the results.

Post-treatment, the cure criterion for individuals with chronic Chagas disease is the persistence of negative parasitological and serological results ${ }^{62527}$.

The present work analyzed the parasitological, serological and clinical evolution of adults with chronic Chagas disease who had no previous electrocardiographic disturbances. They were divided into two groups: a group treated with trypanocide drugs and an untreated (control) group, over a mean follow-up of 21 years.

\section{MATERIAL AND METHODS}

This study was designed as a retrospective and prospective cohort study. At the Centro de Investigaciones sobre Endemias Nacionales (CIEN)*, Santa Fe City, Argentina, a serological, parasitological and clinical follow-up among individuals with chronic Chagas disease living in the city was launched in 1976-1977. This follow-up is still ongoing (2006). Patients were generally monitored every one or two years, although for some of them the gap was longer.

The participants in the follow-up were informed about the study that would be carried out and those who agreed to participate were included in it. Subsequently, and considering age and xenodiagnosis (XD) results, specific antiparasitic treatment was prescribed to one group while the other (control group) received no medication or placebo. There was no spontaneous request for treatment.

During the whole follow-up, the people in the study were living in an area of low endemicity. Most of them shared the characteristic of having migrated from endemic areas, as the probable cause of their T. cruzi infection.

The initial criterion for selection between the treated and untreated groups was to administer the treatment first and foremost to those in whom T. cruzi was detected.

The specific antiparasitic treatment was administered before 1983 , since from that year onwards national norms indicated that chronically infected people should not be treated ${ }^{26}$. The dose and treatment duration were: nifurtimox (Nx) $8-10 \mathrm{mg} / \mathrm{kg} /$ day

*An investigation center for national endemic diseases. over 45-60 days; benznidazole (Bz) $5 \mathrm{mg} / \mathrm{kg} /$ day over 30 days, with half of the dose in the first week, in accordance with the recommendations at the time of administration ${ }^{22}$.

No criterion was applied for selecting which patients were to be treated with $\mathrm{Nx}$ or Bz; the drug available was used.

CIEN provided patients with the medicine for home treatment. They were advised to stop the medication and go immediately for check-up if they suffered any side effects. During and after the treatment, all the patients were monitored through clinical and laboratory examinations. The intolerance reactions recorded were as expressed by the patient.

Three conventional serology (CS) tests was carried out every time the patient went for check-up: indirect hemagglutination (IHA), direct agglutination with 2-mercaptoethanol (DA-2ME) and indirect immunofluorescence (IIF). All the infected people included in this study initially presented reactions in all three of these tests with titers greater than or equal to $1 / 32$. Serum samples were fractionated proportionally and preserved at $-4^{\circ} \mathrm{F}$ and/or refrigerated with glycerin.

The sera obtained at the last of the patients' check-ups were also subjected to two ELISA (enzyme-linked immunosorbent assay) tests: one with cytoplasmic and surface antigens from the parasite and the other with recombinant antigens obtained from specific proteins of the epimastigote and trypomastigote phases of T. cruzi.

Antigens made in the CIEN were used for IHA, DA and IIF tests, while commercial reagents (Wiener, Rosario, Argentina) were used in ELISA tests.

$\mathrm{XD}^{10}$ was used for the parasitological study. It was performed with four entomological boxes per patient, each containing 10 nymphs III of Triatoma infestans that had been starved for a period of three weeks. The boxes were applied to the person's arms and forearms for 30 minutes. The intestinal content of the insects was analyzed 30, 60 and 90 days after the application. XD was performed periodically every two or three check-ups.

The clinical examination was carried out by means of routine laboratory analyses, anamnesis focusing mainly on the circulatory and digestive systems, physical examination, conventional electrocardiogram (EKG) and chest X-ray. Holter monitoring was performed on individuals with Chagas disease whose condition made it necessary and if it was financially possible to do so. Some patients were able to undergo echocardiogram and ergometry. The clinical examination and EKG were carried out every time the patient went for check-up.

The following were considered to be disturbances compatible with chronic Chagas myocardiopathy $(\mathrm{CrChM})^{228}$ : complete right bundle branch block (RBBB); left anterior fascicular block (LAFB) in individuals younger than 50 years old; RBBB + LAFB; frequent ventricular extrasystole (VE); VE associated with conduction disorders; second degree atrioventricular block (AVB); complete AVB; and electrical inactivation areas (no antecedents of ischemic cardiopathy). Although complete left bundle branch block (LBBB) is infrequent in $\mathrm{CrChM}$, it cannot be asserted that it is a consequence of T. cruzi infection. The same occurs with 
sinus bradycardia (SB) less than or equal to 50 beats/min and ventricular repolarization disturbances in several derivations.

Neither radiological nor endoscopic tests on the digestive system were carried out. In the anamnesis, the patient was asked whether they suffered from dysphagia or constipation.

The cure criteria were. 1) Parasitological, through persistent negative results from XD; 2) Serological, when negative seroconversion of CS took place for the three serological reactions (IHA, DA-2ME and IIF); 3) Clinical, through non-appearance of symptoms or electrocardiographic disturbances attributable to Chagas disease.

It was understood that serological titers decreased when the number dropped in two or more dilutions of serum, without reaching negative seroconversion.

Statistical methodology. Chi-square $\left(\mathrm{X}^{2}\right)$ or Fisher's exact test were used as appropriate. Kaplan-Meier curves were used to determine the probability of negative seroconversion after the trypanocide treatment, since these consider the size of the sample as well as the fact that patients were monitored neither simultaneously nor during the same period of time.

\section{RESULTS}

Treated and control (untreated) patients. The study was conducted using comparable groups of patients and taking the following choice criteria into consideration: 1) Three positive serological reactions (IHA; DA-2ME; IIF); 2) Clinically healthy patients, who had no electrographic disturbances and had a normal cardiac area, as checked through chest X-ray; 3) Patients' ages: 17 to 46 years old; 4) Follow-up period: 15 years minimum, 29 years maximum.

Table 1 describes the population: treated group (16 males; 38 females) and control group (19 males; 38 females), divided according to age and drug administered. There was no significant age difference between the groups of patients treated with each drug (the average age of patients treated with $\mathrm{Nx}$ was 30.88 and with $\mathrm{Bz}$ was 31.40).

Table 1 - Chronic Chagas patients treated with nifurtimox or benznidazole and untreated patients, divided into age groups.

\begin{tabular}{lrrrrr}
\hline $\begin{array}{l}\text { Age groups } \\
\text { (years) }\end{array}$ & \multicolumn{3}{c}{ Treated } & & Untreated \\
\cline { 2 - 4 } \cline { 2 - 4 } & $\mathrm{Nx}$ & $\mathrm{Bz}$ & total & total \\
\hline 17 to 26 & 8 & 10 & 18 & 20 \\
27 to 36 & 13 & 9 & 22 & 22 \\
37 to 46 & 6 & 8 & 14 & 15 \\
\hline Total & 27 & 27 & 54 & 57
\end{tabular}

Nx: nifurtimox, Bz: benznidazole

Forty-nine pretreatment $\mathrm{XD}$ were performed on 38 patients, with positive results in 36 (94.7\%) of them: 20 were treated with $\mathrm{Bz}$ and 16 with Nx. Two patients treated with $\mathrm{Bz}$ had previous negative XD.

In the control group, $35 \mathrm{XD}$ were performed on 34 patients, with positive results in 9 (26.5\%) of them.

Follow-up period: the average post-treatment follow-up period was 20.6 years with $\mathrm{Bz}$ and 23.4 years with $\mathrm{Nx}$. The average follow-up period for the control group was 21.7 years. Table 2 shows the number of patients treated with each drug and those belonging to the control group, according to follow-up period and age.

Tolerance of treatment: all the treated patients included in Table 1 completed the treatment. Initially, 33 people were treated with Bz. Among these, two people took it for 20 days and stopped because of maculopapular erythema. Afterwards, they did not receive other trypanocide treatment and, as a result, they were not included in the present study. Four more people started taking $\mathrm{Bz}$ and had to stop the medication because of intolerance. They showed adverse reactions between 10 and 15 days after the treatment had been started. Three of them suffered from maculopapular erythema and the other patient had pruritus, edema and erythema. Twenty-five to 30 days after withdrawal of $\mathrm{Bz}$, these patients started treatment with $\mathrm{Nx}$ and showed great tolerance of it. There was just one patient who suffered from headache, epigastralgia, nausea and dizziness, which was not a reason for stopping the medication.

In the group of patients that completed the treatment with $\mathrm{Bz}$, there was one person who had started with Nx but had to stop after 12 days due to vomiting, headache, anguish and excitation. Twenty days afterwards, treatment with Bz started. It lasted 30 days and the patient showed great tolerance.

The side effects treated patients suffered from are shown in Table 3. Except for the cases described above, other reactions were not reasons for treatment withdrawal.

Although a lower percentage of patients treated with $\mathrm{Bz}$ suffered from side effects than among those treated with $\mathrm{Nx}$ ( $27 \%$ vs $32 \%$ ), the reactions to $\mathrm{Bz}$ were less tolerated, which unavoidably caused treatment withdrawal.

There was no significant difference in the total number of intolerance reactions between these two drugs ( $\mathrm{p}>>0.05)$.

Parasitological control. One hundred and thirty-three post-treatment $\mathrm{XD}$ were performed on 41 patients in the treated group (3 XD/patient), all resulting negative $(100 \%)$.

In the control group, $29 \mathrm{XD}$ were performed on 14 untreated patients (2 XD/patient), of which two resulted positive (14.3\%). The nine patients whose XD was initially positive did not undergo this test again.

Serological control. The diagram in Figure 1 summarizes the evolution of conventional serology tests in the study population.

Table 2 - Number of treated patients, according to drug used, and untreated patients, divided into age groups and length of follow-up.

\begin{tabular}{|c|c|c|c|c|c|c|c|c|}
\hline \multirow{4}{*}{$\begin{array}{l}\text { Age groups } \\
\text { (years) }\end{array}$} & \multicolumn{8}{|c|}{ Length of follow-up } \\
\hline & \multicolumn{3}{|c|}{$15-19$ years } & \multicolumn{3}{|c|}{$20-24$ years } & \multicolumn{2}{|c|}{$>24$ years } \\
\hline & \multicolumn{2}{|c|}{ treated } & \multirow[b]{2}{*}{ untreated } & \multicolumn{2}{|c|}{ treated } & \multirow[b]{2}{*}{ untreated } & treated & \multirow[b]{2}{*}{ untreated } \\
\hline & $\mathrm{NX}$ & $\mathrm{Bz}$ & & $\overline{N X}$ & $\mathrm{Bz}$ & & $\mathrm{Bz}$ & \\
\hline 17 to 26 & 1 & 5 & 7 & 3 & 4 & 8 & 4 & 5 \\
\hline 27 to 36 & 3 & 4 & 7 & 5 & 3 & 13 & 5 & 2 \\
\hline 37 to 46 & 1 & 2 & 1 & 2 & 3 & 9 & 3 & 5 \\
\hline Total & 5 & 11 & 15 & 10 & 10 & 30 & 12 & 12 \\
\hline$\%$ & 18.5 & 40.7 & 26.3 & 37.1 & 37.1 & 52.6 & 44.4 & 21.1 \\
\hline
\end{tabular}

Nx: nifurtimox, Bz: benznidazole 


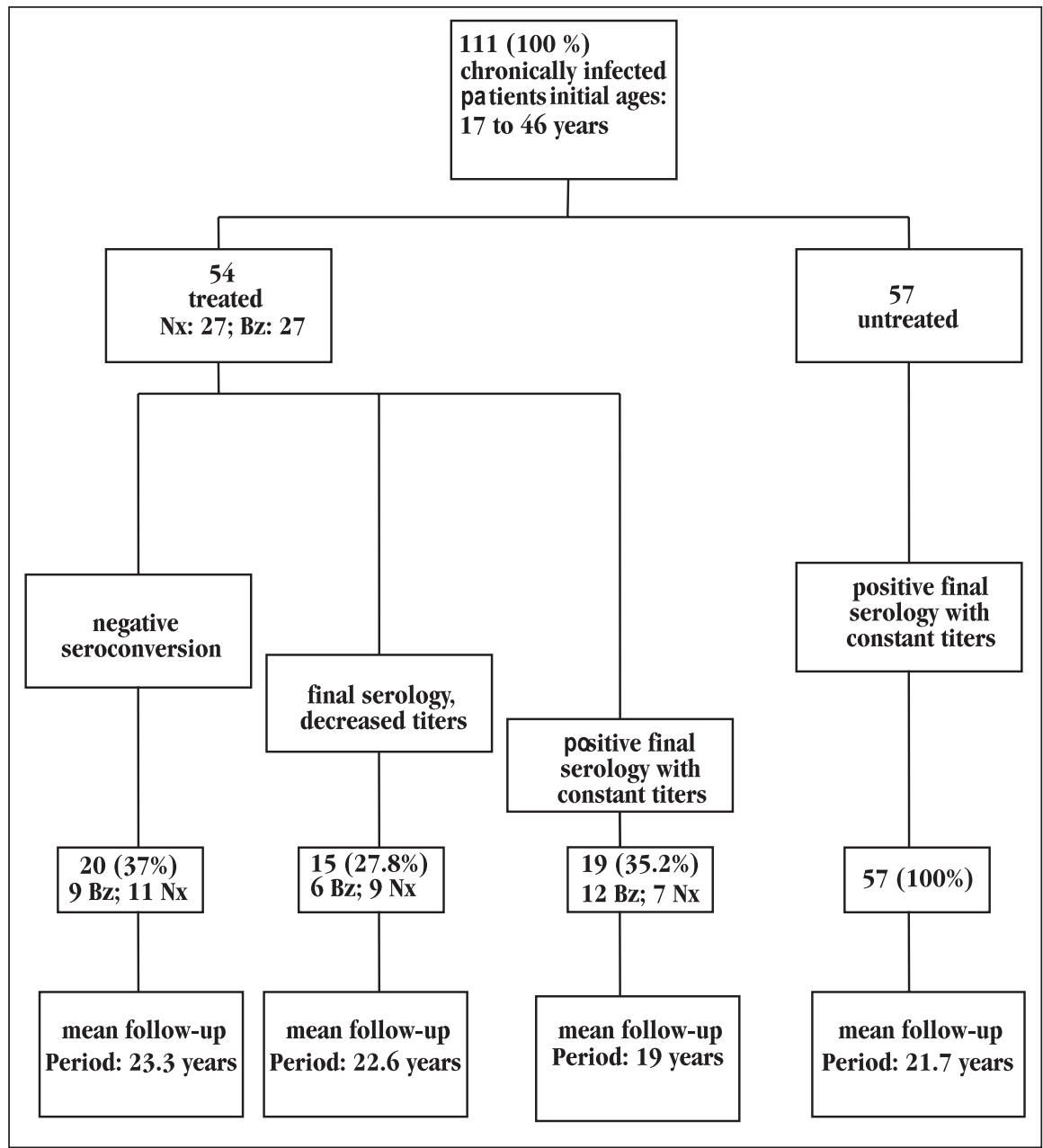

Figure 1 - Serological evolution of chronic chagasic infected patients, treated and untreated, during an average 21 years follow-up period.

Table 3 - Side effects from trypanocide treatment, according to drug used (nifurtimox and benznidazole).

\begin{tabular}{lrrrrr}
\hline \multirow{2}{*}{$\begin{array}{l}\text { Side effects/number of } \\
\text { treated patients }\end{array}$} & \multicolumn{2}{c}{ Nifurtimox } & & \multicolumn{2}{c}{ Benznidazole } \\
\cline { 2 - 3 } \cline { 5 - 6 } $\mathrm{n}^{\mathrm{0}}$ & & & $\mathrm{n}^{\mathrm{0}}$ & $\%$ \\
\hline None & $19 / 28$ & 68.0 & $24 / 33$ & 73.0 \\
Side effects & $9 / 28$ & 32.0 & $9 / 33$ & 27.0
\end{tabular}

Adverse reactions recorded, separately or in association

\begin{tabular}{lcc}
\hline & $\mathrm{Nx}$ & $\mathrm{Bz}$ \\
Maculopapular erythema & 0 & 6 \\
Edema & 0 & 3 \\
Nausea & 3 & 1 \\
Weight loss - anorexia & 3 & 0 \\
Dizziness & 2 & 0 \\
Insomnia & 2 & 0 \\
Gastralgia & 1 & 0 \\
Headache & 0 & 1 \\
Anguish and excitation & 1 & 0 \\
Pruritus & 0 & 1 \\
Vomiting & 1 & 0 \\
Slight increase in transaminases & 1 & 1 \\
\hline
\end{tabular}

Nx: nifurtimox; Bz: benznidazole.

No significant differences were observed between the two drugs, in relation to the total number of intolerance reactions (chi-square test $\mathrm{p}>>0.05$ )

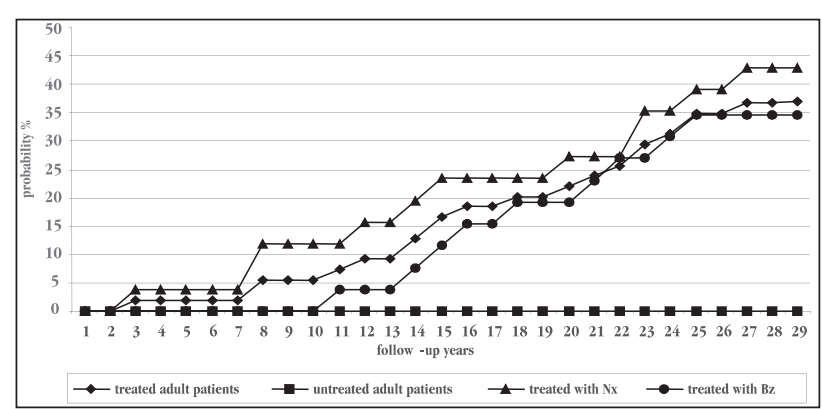

Figure 2 - Probability of negative seroconversion in adult patients with chronic Chagas disease, treated with nifurtimox and/or benznidazole and untreated, over the course of time.

The sera from the 111 patients with chronic Chagas disease, obtained at the different check-ups throughout the follow-up, were processed simultaneously and quantitatively.

Among the 54 treated patients: A) Twenty (37\%) had negative seroconversion; 9 (45\%) were treated with $\mathrm{Bz}$ and $11(55 \%)$ with Nx (Table 4). The average length of time for negative seroconversion was 16 years post-treatment. In 13 patients, of whom four had previously had fluctuating serology (positive serology at some check-ups and negative at others), this length of time was greater than or equal to 20 years. The remaining seven patients achieved persistent negative seroconversion 
between 8 and 17 years after the treatment had been completed. B) Fifteen $(27.8 \%)$ presented decreased titers, and nine of them showed inconclusive final serology (some tests were reactive to $1 / 32$ titers and others were non-reactive) (seven treated with $\mathrm{Nx}$ and two with $\mathrm{Bz}$ ). C) Nineteen (35.2\%) did not present altered serological titers.

In the control group (untreated patients), the initial titers remained constant throughout the study (Table 5).

Figure 2 (Kaplan-Meier curves) shows that the probability of negative seroconversion in adult patients treated with $\mathrm{Nx}$ was higher and took place earlier than with Bz. From this experience, it can be deduced that 27 years post-treatment are required for $43 \%$ of those treated with $\mathrm{Nx}$ to show non-reactive conventional serology test results.

For benznidazole, the earliest time until negative seroconversion was 11 years, and for that to take place in $32 \%$ of the population who received this medication, 25 years post-treatment was required.

There was no probability of negative seroconversion in the untreated infected patients.

Clinical control. Although digestive system tests were not carried out, it was inferred from the anamnesis that none of the groups suffered from dysphagia during the follow-up. One patient who had considerable constipation (more than five days) suffered from elongated colon (she was treated with $\mathrm{Nx}$ and presented post-treatment negative seroconversion of CS; 26 years later, she does not present either electrocardiographic disturbances or cardiac symptomatology).

The diagram in Figure 3 shows the electrocardiographic evolution of adults with chronic Chagas disease infection who were initially asymptomatic, over the course of the study period.

Within the treated group $(n=54)$, six patients showed disturbances on EKG during the follow-up, while in the control group $(n=57)$ electrical alterations were found in 14 patients. Table 6 shows their impact according to age and the drug used. All patients, both treated and untreated, who showed abnormalities on EKG remained with positive CS, except for one person treated with $\mathrm{Bz}$ who developed LBBB at the age of 50, suffering from chronic arterial hypertension (cardiac cavities of a normal size and preserved left ventricular systolic function).

The kind of electrocardiographic and radiological abnormalities, the age at which they started to be detected and the presence or absence of associated pathologies in the treated and control groups are shown in Tables 7 and 8 respectively.

Patients in both groups in whom arrhythmia was detected declared that they felt palpitations. None of the patients lost their functional capacity to make normal efforts. Auscultation showed neither heart murmur nor presence of a third noise.

In the pulmonary auscultation, no rales suggesting left heart failure were found and no signs of right heart failure were detected (no jugular ingurgitation, no edema and no hepatomegaly).

Abnormalities found in patients 3 and 5 of Table 7 were considered attributable to CrChM. Both of these patients showed disturbances on electrocardiogram two years after the treatment

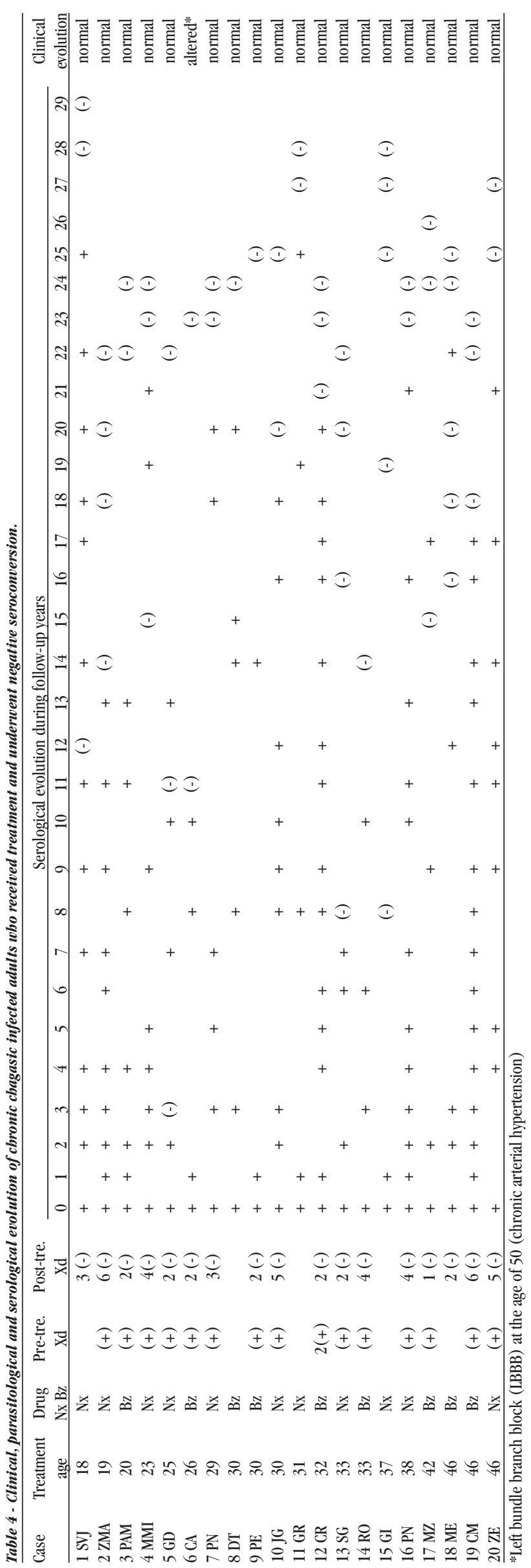




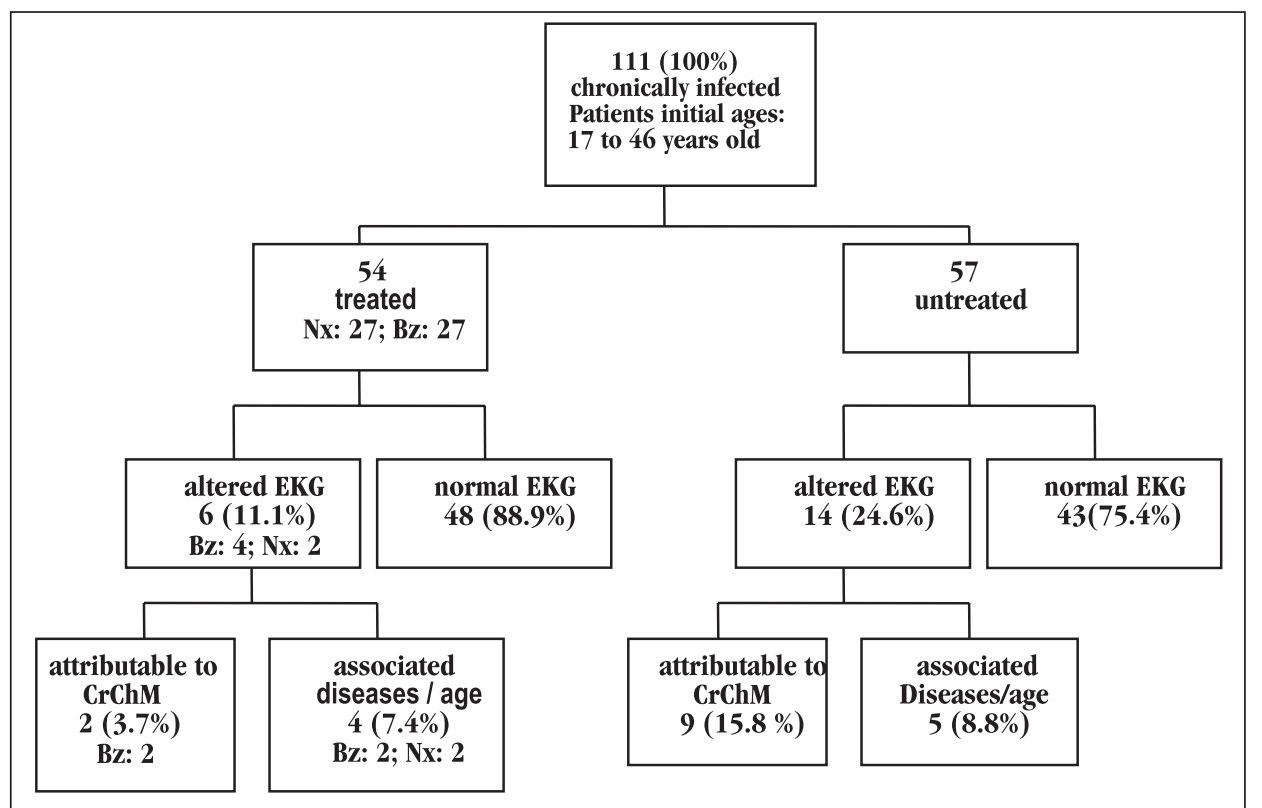

Figure 3 - Electrocardiographic evolution of chronic chagasic infected patients, treated and untreated, who had no initial electrical disturbances, in an average 21 years follow-up period.

Table 5 - Serological evolution of patients with chronic Chagas disease (treated and untreated), according to age groups and follow-up period.

\begin{tabular}{|c|c|c|c|c|c|c|c|c|c|}
\hline \multirow{4}{*}{$\begin{array}{c}\text { Age } \\
\text { groups } \\
\text { (years) }\end{array}$} & \multirow{4}{*}{$\begin{array}{c}\text { mean follow-up } \\
\text { period } \\
\text { in years }\end{array}$} & \multirow{4}{*}{$\begin{array}{l}\text { number } \\
\text { of } \\
\text { patients }\end{array}$} & \multicolumn{4}{|c|}{ Treated patients } & \multicolumn{3}{|c|}{ Untreated patients } \\
\hline & & & \multicolumn{4}{|c|}{ evolution of titers } & \multirow{3}{*}{$\begin{array}{c}\text { mean follow-up } \\
\text { period } \\
\text { in years }\end{array}$} & \multirow{3}{*}{$\begin{array}{c}\text { number of } \\
\text { patients }\end{array}$} & \multirow[b]{2}{*}{$\begin{array}{c}\text { evolution of titers } \\
\text { constant }\end{array}$} \\
\hline & & & \multicolumn{2}{|c|}{ constant } & decrease & $\begin{array}{c}\text { negative } \\
\text { seroconversion }\end{array}$ & & & \\
\hline & & & & $\%$ & $\mathrm{n}^{0} \quad \%$ & $\mathrm{n}^{0} \quad \%$ & & & $\mathrm{n}^{\underline{0}}$ \\
\hline 17 to 26 & 20.8 & 18 & 8 & 44.5 & 422.2 & $\begin{array}{ll}6 & 33.3\end{array}$ & 21.8 & 20 & 20100,0 \\
\hline 27 to 36 & 22 & 22 & 6 & 27.2 & 836.4 & 836.4 & 20 & 22 & 22100,0 \\
\hline 37 to 46 & 22.7 & 14 & 5 & 35.7 & 321.4 & $\begin{array}{ll}6 & 42.9\end{array}$ & 22.7 & 15 & 15100,0 \\
\hline Total & 21.8 & 54 & 19 & 35.2 & $15 \quad 27.8$ & 2037.0 & 21.6 & 57 & $57 \quad 100,0$ \\
\hline
\end{tabular}

had been completed. In patient 3, who received treatment with $\mathrm{Bz}$ at the age of 29, VE and SB were detected two years later. Twenty years later, he showed LAFB and was suffering from arterial hypertension.

In the other patient (№ 5), who was treated with Bz at the age of 31, VE, electrical inactivation area (QS in V1 and V2) and ventricular repolarization disturbances were detected two years later. Twelve years later, she developed grade I cardiomegaly, and echocardiogram showed a slight increase in left cardiac cavity size with slight wall hypokinesia. In the ergometric test, polyfocal ventricular arrhythmia and dyspnea when reaching $750 \mathrm{kgm} / \mathrm{m}$ (6.42 METs) were detected.
Table 6 - Incidence of electrocardiographic disturbances in patients with chronic Chagas disease (treated and untreated), according to age groups.

\begin{tabular}{lrrrc}
\hline & \multicolumn{4}{c}{ Number of patients with altered EKG/Total } \\
\cline { 2 - 4 } Age groups & \multicolumn{3}{c}{ treated } & $\begin{array}{c}\text { untreated } \\
\text { tyears) }\end{array}$ \\
\cline { 2 - 4 } & $\mathrm{Nx}$ & $\mathrm{Bz}$ & total & $2 / 20$ \\
\hline 17 to 26 & $1 / 8$ & $1 / 10$ & $2 / 18$ & $6 / 22$ \\
27 to 36 & $1 / 13$ & $3 / 9$ & $4 / 22$ & $6 / 15$ \\
37 to 46 & $0 / 6$ & $0 / 8$ & $0 / 14$ & $14 / 57$ \\
\hline Total & 227 & $4 / 27$ & $6 / 54$ &
\end{tabular}

Nx: nifurtimox; Bz: benznidazole. All the patients with disturbances on EKG remained with positive CS, except for one patient treated with Bz who showed negative seroconversion and, when suffering from chronic arterial hypertension, showed LBBB at the age of 50 .

Table 7 - Electrocardiographic and radiological disturbances shown by the treated group.

\begin{tabular}{|c|c|c|c|c|c|c|c|c|}
\hline № & Patient & G & $\mathrm{T}$ & $\begin{array}{c}\mathrm{T} \\
\text { age }\end{array}$ & $\begin{array}{c}\text { EKG } \\
\text { disturb age }\end{array}$ & EKG disturb & chest X-ray & $\begin{array}{c}\text { associated } \\
\text { diseases }\end{array}$ \\
\hline 1 & VAM & $\mathrm{F}$ & Nx & 20 & 37 & $\mathrm{PR}=0.20$ to 0.24 & normal & none \\
\hline 2 & $\mathrm{CA}$ & $\mathrm{F}$ & $\mathrm{Bz}$ & 26 & 50 & LBBB & normal & hypertension \\
\hline 3 & $\mathrm{ChR}$ & M & $\mathrm{Bz}$ & 29 & 31 & $\mathrm{VE}+\mathrm{SB}+\mathrm{LAFB}$ & normal & none (later: hypertension) \\
\hline 4 & SA & $\mathrm{F}$ & $\mathrm{Bz}$ & 30 & 53 & LAFB & normal & hypertension \\
\hline 5 & AN & $\mathrm{F}$ & $\mathrm{Bz}$ & 31 & 33 & $\mathrm{VE}+\mathrm{LAFB}$ & grade I cmeg & none (later: diabetes) \\
\hline 6 & IC & M & Nx & 36 & 59 & IRBBB + LAFB & normal & hypertension + obesity + diabetes \\
\hline
\end{tabular}


Diabetes was detected at this check-up and two years later she developed LAFB.

Neither of these two patients ( 3 and 5) who developed myocardiopathy underwent negative seroconversion of CS.

The electrical disturbances that the other four patients showed cannot be exclusively attributed to $\mathrm{CrChM}$ (due to type of disturbance, age and/or associated diseases), as described below.

Patient 1 showed electrocardiographic abnormalities with PR from 0.20 to 0.24 . This disturbance remained constant 13 years after it first appeared.

An EKG on patient 2 at the age of 50 years showed LBBB with PR of $0.16 \mathrm{sec}$. The LBBB may have been attributable to Chagas infection but this patient was suffering from arterial hypertension that had evolved over the preceding five 5 years and, although medicated with enalapril (20mg/day), she remained hypertensive $(145 / 100 \mathrm{~mm} \mathrm{Hg})$. An echocardiogram showed that the left ventricle had normal size (LVIDd: $52 \mathrm{~mm}$ ), the ejection fraction was preserved (EF 70\%) and the left auricle slightly dilated ( $42 \mathrm{~mm}$ ). In a previous EKG there had been no evidence of conduction disorders.

Patient 4, who suffered from chronic hypertension, developed LAFB at the age of 53 .

Patient 6 showed LAFB at the age of 59 and suffered from associated diseases like arterial hypertension, obesity and diabetes.

All the treated patients who showed disturbances on EKG continued to have positive CS, except for patient 2 . She underwent negative seroconversion, but taking into account the age at which lesions appeared and the presence of chronic arterial hypertension, her electrical disturbances cannot be attributed to $\mathrm{CrChM}$.

Table 8 shows the types of abnormalities on EKG among the patients with untreated Chagas disease. In nine of the patients
$(2,3,6,7,8,9,10,11$ and 14$)$ the disturbances were considered to be signs of CrChM.

The remaining five patients suffered disturbances that were not considered to be signs of $\mathrm{CrChM}$ because:

Patient 1 showed LAFB at the age of 52 and, although he had no associated diseases, the conduction disorder cannot be attributed with certainty to $T$. cruzi infection because of the age at which it appeared.

Patient 4 showed PR between 0.20 and 0.22 and left-axis QRS.

Patient 5 developed LAFB at the age of 51 and suffered from chronic arterial hypertension.

Patient 12 showed VE and LAFB at the age of 54 , suffering from arterial hypertension and diabetes for 13 years before showing this disturbance on the electrocardiogram.

Patient 13 showed LAFB and LVO (left ventricular overload) at the age of 50 and suffered from chronic arterial hypertension.

The incidence of electrographic disturbances attributable to CrChM in both groups of patients with Chagas disease (treated and untreated) is summarized in Table 9.

Comparison between the proportions of patients who became ill in the treated infected group (2/54) and in the untreated infected group (9/57) revealed statistically significant differences ( $p>0.05)$.

It is important to emphasize that the proportion of patients who became ill without being treated was approximately four times higher than that of the treated group.

Neither the presence of associated diseases (diabetes, hypertension and obesity) nor the occurrence electrocardiographic disturbances at the age of 50 or later ( $4 / 54$ in the treated patients and 5/57 in the untreated patients) showed significant differences between the groups ( $p>>0.05$ ).

\begin{tabular}{|c|c|c|c|c|c|c|c|}
\hline № & Patient & G & Age & $\begin{array}{c}\text { EKG } \\
\text { disturb } \\
\text { age } \\
\end{array}$ & EKG disturb & Chest X-ray & $\begin{array}{c}\text { Associated } \\
\text { diseases }\end{array}$ \\
\hline 1 & $\mathrm{RR}$ & M & 24 & 52 & LAFB & normal & none \\
\hline 2 & CAM & $\mathrm{F}$ & 24 & 25 & $\mathrm{VE}$ & normal & none \\
\hline 3 & SA & $\mathrm{F}$ & 27 & 44 & $\mathrm{VE}$ & normal & none \\
\hline 4 & $\mathrm{FH}$ & $\mathrm{F}$ & 28 & 44 & $\mathrm{PR}=0.20-0.22$; left-axis $\mathrm{QRS}$ & normal & none \\
\hline 5 & PdelP & $\mathrm{F}$ & 30 & 51 & LAFB & normal & hypertension \\
\hline 6 & SM & $\mathrm{F}$ & 31 & 40 & LAFB + Repol disturb & normal & hypertension \\
\hline 7 & $\tilde{N} M$ & $\mathrm{~F}$ & 31 & 42 & RBBB & grade I cmeg & none \\
\hline 8 & $\mathrm{VJ}$ & $\mathrm{F}$ & 33 & 45 & $\mathrm{LAFB}+1^{\text {st }}$ degree AVB + RBBB & grade I cmeg & none \\
\hline 9 & $\mathrm{BA}$ & $\mathrm{F}$ & 37 & 49 & $\mathrm{RBBB}+\mathrm{LAFB}$ & normal & hypertension \\
\hline 10 & $\mathrm{VE}$ & M & 38 & 49 & $\mathrm{VE}+\mathrm{SB}+\mathrm{T}(-)+$ Septal Fibrosis & normal & none \\
\hline 11 & MC & M & 38 & 48 & $\mathrm{IRBBB}+\mathrm{SB}+\mathrm{VE}$ & normal & none \\
\hline 12 & $\mathrm{AF}$ & $\mathrm{F}$ & 39 & 54 & $\mathrm{VE}+\mathrm{LAFB}$ & normal & hypertension + diabetes \\
\hline 13 & $\mathrm{FA}$ & M & 40 & 50 & LAFB + LVO & normal & hypertension \\
\hline 14 & MS & $\mathrm{F}$ & 43 & 46 & LAFB & normal & none \\
\hline
\end{tabular}


Table 9 - Incidence of electrocardiographic disturbances compatible with Chagas myocardiopathy in treated and untreated patients.

\begin{tabular}{lrrrr}
\hline & \multicolumn{4}{c}{ Sick people/total patients } \\
\cline { 2 - 4 } $\begin{array}{l}\text { Age groups } \\
\text { years) }\end{array}$ & $\mathrm{Nx}$ & $\mathrm{Bz}$ & total & untreated \\
\cline { 2 - 4 } \cline { 5 - 5 } 17 to 26 & $0 / 8$ & $0 / 10$ & $0 / 18$ & \\
27 to 36 & $0 / 13$ & $2 / 9$ & $2 / 22$ & \\
37 to 46 & $0 / 6$ & $0 / 8$ & $0 / 14$ & $4 / 22$ \\
\hline Total & $0 / 27$ & $2 / 27$ & $2 / 54\left(^{*}\right)$ & $9 / 57^{*}$ \\
\hline
\end{tabular}

Sick people/total of patients: number of patients who showed electrocardiographic disturbances during the follow-up period, over the total number of infected people who received treatment or not. Nx: nifurtimox; Bz: benznidazole.

(Chi-square test; $\mathrm{p}=0.028$ )

*negative seroconversion was not observed in any of the patients who became ill.

Parasitological, serological and clinical control. Treated patients who underwent negative seroconversion also showed negative XD after the treatment. All these patients remained without signs or symptoms of CrChM.

No significant differences were observed regarding cure percentage and incidence of electrocardiographic disturbances ( $p>>0.05$ ) between patients treated with $\mathrm{Bz}$ and those treated with Nx (Tables 10 and 11).

\begin{tabular}{|c|c|c|c|c|}
\hline Treated & $\begin{array}{c}\text { Persistent } \\
\text { positive }\end{array}$ & $\begin{array}{c}\text { Persistent } \\
\text { negative }\end{array}$ & Total & $\begin{array}{l}\text { Cure } \\
(\%) \\
\end{array}$ \\
\hline $\mathrm{Bz}$ & 12 & 9 & 21 & 42.9 \\
\hline $\mathrm{Nx}$ & 7 & 11 & 18 & 61.1 \\
\hline Total & 19 & 20 & 39 & 51.3 \\
\hline
\end{tabular}

All the patients who underwent negative seroconversion remained with no signs or symptoms of CrChM.

There are no significant differences as regards the cure percentage in patients treated with $\mathrm{Bz}$ and $\mathrm{Nx}$.

(Chi-square test $\mathrm{p}>>0.05$ ) Patients who showed a decrease in titers were excluded.

Table 11 - Appearance of disturbances in the EKG of patients treated with $N x$ or Bz.

\begin{tabular}{|c|c|c|c|c|}
\hline \multirow{3}{*}{ Treated } & \multicolumn{2}{|c|}{ altered EKG } & \multirow{3}{*}{$\begin{array}{c}\text { Normal } \\
\text { ECG }\end{array}$} & \multirow{3}{*}{ Tota } \\
\hline & sign & no sign & & \\
\hline & CrChM & CrChM & & \\
\hline $\mathrm{Bz}$ & 2 & 2 & 23 & 27 \\
\hline $\mathrm{Nx}$ & 0 & 2 & 25 & 27 \\
\hline Total & 2 & 4 & 48 & 54 \\
\hline
\end{tabular}

Tre: treatment; sign CrChM: disturbances in the EKG which are a sign of chagasic etiology; no sign CrChM: disturbances in the EKG which are not a sign of chagasic myocardiopathy.

There are no significant differences in the incidence of electrocardiographic disturbances between patients treated with $\mathrm{Nx}$ and $\mathrm{Bz}$ (Fisher's exact test $\mathrm{p}>>0.05$ )

\section{DISCUSSION}

In previous publications, we have shown that the decrease in serological titers among this cohort of adults with chronic Chagas disease was statistically significant in comparison with that of the group of infected people who did not receive treatment. The treated individuals also had better clinical evolution, although this was not statistically relevant ${ }^{1718}$.

In the present study, with a longer follow-up period, negative seroconversion was observed in $37 \%$ of the treated adult patients, as well as statistically significant differences in the clinical evolution, in comparison with the control group ( $\mathrm{p}>0.05)$.

These results coincide with other investigators' findings $\mathrm{s}^{32}$. Using the same doses and administration period for $\mathrm{Bz}$ $(5 \mathrm{mg} / \mathrm{kg} /$ day over 30 days $)$, Viotti et al showed that after eight years of follow-up there was less deterioration in clinical condition ( $2.1 \%$ in the treated patients vs $17 \%$ in the untreated patients), increased frequency of negative seroconversion and decreased titers in the treated group, in comparison with the untreated group.

In follow-ups on children with chronic Chagas disease who received treatment with $\mathrm{Nx}$ or $\mathrm{Bz}$ up to the age of 14, we observed a significant percentage of negative seroconversion of CS $(59 \%)^{30}$. Such a significant negative seroconversion had not been observed in adults with chronic infection.

In children with chronic infection, the lower the age of the treated patient was, the higher the probability of negative seroconversion also was ${ }^{162130}$, as it is connected with the pretreatment period of the infection. In the present study, however, the serological evolution had no connection with the age at which infected adults were treated.

Although it is difficult to know for certain when each patient became infected, it is possible to infer that this occurred as many years ago as the age they are, because most of them were born and/or grew up in endemic areas. Moreover, one of the conditions for being part of this study was that they had to remain in Santa Fe city, which is an area of low endemicity, and they were excluded if they returned to an endemic area, even for a brief period.

Although it is known that two concordant serological reactions in the cohort titers indicate Chagas infection, it is necessary to point out that most of the infected patients whose XD was positive received treatment. This was so because when we started this cohort study our experience was just beginning and, in order to confirm the infection, we had to show not only serology but also the presence of T. cruzi. This explains the lack of randomization of the groups in this respect, but this does not imply introducing any significant bias in the study, since the low sensitivity of XD during the chronic phase of the infection is well-known. Positive parasitological results recorded before the trypanocide treatment was administered, and many negative XD after its administration, showed at least a decrease in parasitic load.

At the end of the 1970s, the only drug available in our Center was Nx, and that is why the follow-up period for patients treated with this drug is longer than the follow-up for those treated with Bz. Negative seroconversion, together with a notable decrease in titers in the group with inconclusive final serology, were found more frequently in patients treated with $\mathrm{Nx}(19 / 27)$ than in those who received $\mathrm{Bz}$ (11/27). Although the follow-up period with this drug was shorter, there is a question mark over the clinical and serological effectiveness that $\mathrm{Bz}$ would have presented if the treatment had been carried on for 60 days.

Treatment duration may have an influence on cure rates, but the serious toxic effects from $\mathrm{Bz}$ when the total dose reaches approximately 18 grams are well-known ${ }^{7}$.

In our study, the most frequent adverse reaction in patients treated with Bz was maculopapular erythema (Table 3). No cases 
of polyneuritis or other more serious side effects were observed ${ }^{11}$, and this was probably due to the lower total dose of the drug administered.

Among the treated patients, two developed electrocardiographic disturbances compatible with $\mathrm{CrChM}$. Abnormalities were detected two years after the treatment with $\mathrm{Bz}$ had been completed. This short post-treatment period lead us into thinking that, by carrying out more complex initial tests (Holter, ergometry and electrophysiological tests), the disturbances could possibly have been detected earlier.

During this long study period, only two patients out of those treated with $\mathrm{Nx}(\mathrm{n}=27)$ showed disturbances on EKG. In one case, the abnormalities could not be attributed to the disease (PR of 0.20 to 0.24 ) and in the other, they appeared when the patient was 59 years old (IRBBB + ILAFB) and was also suffering from associated diseases (hypertension, diabetes and obesity).

The incidence of electrographic disturbances in the treated group that were not considered to be $\mathrm{CrChM}$, because of the age at which LAFB appeared (50 years old) and associated diseases, such as diabetes, arterial hypertension and obesity (4/54 patients), was similar to the incidence in the control group (5/57).

Although the pathogenic mechanisms for Chagas disease are unclear, the findings from this study prove that T. cruzi eradication may be a prior requirement for preventing the development of the disease $\mathrm{e}^{45}$.

Some experimental studies have described the existence of strains that are naturally resistant to $\mathrm{Nx}$ and $\mathrm{Bz}$, which could explain the different responses to treatment.

Despite the limitations of the available trypanocide drugs ${ }^{81129}$, the results from the present study show that the treatment brought about a cure in at least $37 \%$ of the patients, since they showed negative seroconversion, and that it had a protective effect on the clinical evolution of the disease in chronically infected adults.

\section{ACKNOWLEDGMENTS}

The authors thank the staff of the Departamento de Matemáticas de la Facultad de Bioquímica y Ciencias Biológicas de la Universidad del Litoral for their cooperation in providing support for the statistical analysis.

\section{REFERENCES}

1. Andrade ALS, Zicker F, Oliveira RM, Silva SA, Luquetti A, Travassos L, Almeida IC, Andrade S, Andrade JG, Martelli C. Randomised trial of efficacy of benznidazole in treatment of early Trypanosoma cruzi infection. The Lancet 348:1407-1413, 1996.

2. Arias E, Streiger M, Demonte M, Fabbro D, del Barco M. Alteraciones electrocardiográficas en preconscriptos con serología positiva y negativa para infección chagásica en áreas de la provincia de Santa Fe. Revista Argentina de Cardiología 62: 69-74, 1994.

3. Barclay CA, Cerisola JA, Lugones H, Ledesma 0, Silva L, Bouzo G. Aspectos farmacológicos y resultados terapéuticos del benznidazol en el tratamiento de la infección chagásica. La Prensa Médica Argentina 65:239-244, 1978.
4. Bellotti G, Bocchi EA, Moraes AV. In vivo detection of Trypanosoma cruzi antigens in hearts of patiens with chronic Chagas' heart disease. American Heart Journal 131:301-307, 1996.

5. Brandariz S, Schijman A, Vigliano C, Viotti R, Levin MJ. Role of parasites in the pathogenesis of Chagas'cardiomyopathy. Lancet 347: 914, 1996.

6. Cançado JR. Criteria of Chagas Disease Cure. Memórias do Instituto Oswaldo Cruz 94:331-335, 1999.

7. Cançado JR. Long term evaluation of etiological treatment of Chagas disease with benznidazole. Revista do Instituto de Medicina Tropical de São Paulo 44:1-21, 2002.

8. Castro J, Toranzo ED. Toxic effects of Nifurtimox and Benznidazole. Two drugs used against American Trypanosomiasis (Chagas' disease). Biomedical and Environmental Sciences 1:19-33, 1988.

9. Cerisola JA. Chemotherapy of Chagas infections in man. Scientific Publication Pan American Health Organization $N^{\circ}$ 347, 1977.

10. Cerisola JA, Rohweder R, Segura EL, Del Prado CE, Alvarez M, Martini GJW. El xenodiagnóstico. Normatización. Instituto Nacional de Diagnóstico e Investigación de la Enfermedad de Chagas (INDIECH), Buenos Aires, Argentina 1974.

11. Coura JR, Castro SL. A Critical Review on Chagas Disease Chemotherapy. Memórias Do Instituto Oswaldo Cruz 97:3-24, 2002.

12. Cunha-Neto E, Coelho V, Guilherme L, Fiorelli A, Stolf N, Kalil J. Autoimmunity in Chagas'disease: identification of cardiac myosin B13 Trypanosoma cruzi protein cross-reactive T cell clones in heart lesions of chronic Chagas' cardiomyopathy patient. Journal Clinical Investigation 98:1709-1712, 1996.

13. Dávila EV, Streiger M, Bovero N, Fabbro D. Comparación de 3 reacciones serológicas para infección chagásica. Acta Bioquímica Clínica Latino Americana 16:99-102, 1982.

14. Duschak V, Riarte A, Segura E, Laucella S. Humoral inmune response to cruzipain and cardiac dysfunction in chronic Chagas disease. Immunology Letters 78:135$142,2001$.

15. Engman D, Leon J. Pathogenesis of Chagas heart disease: role of autoimnunity. Acta Tropica 81:123-132, 2002.

16. Estani SS, Segura EL, Ruiz AM, Velazquez E, Porcel BM, Yampotis C. Efficacy of chemoterapy with benznidazole in children in the indeterminate phase of Chagas'disease. American Journal of Tropical Medicine and Hygiene 59:526-29, 1998

17. Fabbro D, Arias E, Streiger M, del Barco M, Amicone N, Miglietta H. Evaluación de la quimioterapia específica en infectados chagásicos adultos en fase indeterminada con más de quince años de seguimiento. Revista de la Federación Argentina de Cardiología 30:496-503, 2001.

18. Fabbro D, Arias E, Streiger M, Piacenza M, Ingaramo M, del Barco M, Amicone N. Evolutive behavior towards cardiomyopathy of treated (nifurtimox or benznidazole) and untreated chronic chagasic patients. Revista do Instituto de Medicina Tropical de São Paulo 42:99-109, 2000.

19. Ferreira HO. Tratamento da forma indeterminada da doença de Chagas com nifurtimox e benznidazol. Revista da Sociedade Brasileira de Medicina Tropical 23:209-211, 1990.

20. Filardi LS, Brener Z. Susceptibity and natural resistance of Trypanosoma cruzi strains to drugs used clinically in Chagas disease. Transactions of the Royal Society of Tropical Medicine and Hygiene 81:755-759, 1987.

21. Freilij H, Altcheh J. Respuesta terapéutica al nifurtimox en pacientes de edad pediátrica con enfermedad de Chagas crónica. Revista de Patología Tropical 27:17-19, 1998.

22. Jörg ME. Trypanosomiasis Cruzi Humana o Enfermedad de Chagas. Actualización de Tratamiento. 1/74 ROCHE Cardiología Año XXIX Nº 380, mayo 1974.

23. Laguens R, Meckert PC, Vigliano C. Patogenia de la miocarditis chagásica crónica humana. Medicina (Bs. As.) 59:63-68, 1999.

24. Libonatti E, Manzullo E, Darraidou M, Quiñones G, Morgade S, Libonatti 0. Seguimiento longitudinal de 4.441 chagásicos crónicos en nueve años. Buenos Aires. Asociación Médica Argentina 1:35-48,1980.

25. Luquetti A. The National Health Foundation of Brazil etiological treatment for Chagas disease. Parasitogy Today 13:127-128, 1997.

26. Ministerio de Salud y Acción Social y COFESA. Normas para Atención médica del infectado chagásico. Buenos Aires, Argentina. Noviembre de 1983. 
27. Rassi A, Luquetti A. Therapy of Chagas disease. In: Wendel S, Brener Z, Camargo ME, Rassi A (eds) Chagas Disease (American trypanosomiasis): its impact on transfusion and clinical medicine. International Society of Blood Transfusions, Brazil ‘92, São Paulo, Brazil, p.37-247, 1992.

28. Schenone H, Olea JP, Contreras M, Borgoño JM. Cardiopatía chagásica crónica en Chile. Frecuencia de electrocardiogramas alterados en 13.515 habitantes rurales y periurbanos de áreas de endemia chagásica con serología positiva 0 negativa. Boletin Chileno de Parasitología 43:18-21, 1988.

29. Stoppani A. Quimioterapia de la enfermedad de Chagas. Medicina 59:147-165, 1999.

30. Streiger ML, del Barco ML, Fabbro DL, Arias ED, Amicone NA. Estudo longitudinal e quimioterapia específica em crianças, com doença de Chagas crônica, residentes em área de baixa endemicidade da República Argentina. Revista da Sociedade Brasileira de Medicina Tropical 37:365-375, 2004.

31. Tarleton RL, Zhang L. Chagas Disease Etiology. Autoimmunity or Parasite Persistence? Parasitology Today 15:94-99, 1999.

32. Viotti R, Vigliano C, Armenti H, Segura E. Treatment of chronic Chagas disease with benznidazole: clinical and serologic evolution of patients with long term follow-up. American Heart Journal 127: 151-162, 1994.

33. Veloso VM, Carneiro CM, Toledo MJO, Lana M, Chiari E, Tafuri WL, Bahia MT. Variation in susceptibility to Benznidazole in isolates derived from Trypanosoma cruzi parental strains. Memorias do Instituto Oswaldo Cruz 98: 1005-1011, 2001 